\title{
Repeat injections of replenishing primitive magma recorded in gabbros of the Atlantis Bank oceanic core complex
}

\author{
TERESA UBIDE ${ }^{1}$, DAVID T MURPHY ${ }^{2}$ AND BALZ S \\ KAMBER $^{2}$
}

${ }^{1}$ The University of Queensland

${ }^{2}$ Queensland University of Technology

Presenting Author: t.ubide@uq.edu.au

Radiogenic and noble gas isotopes in mid-ocean-ridge basalts (MORBs) as direct proxies of the upper mantle have refined the understanding of elemental cycling through Earth's silicate reservoirs. By contrast, major and trace element systematics of MORB are modified during the building of oceanic crust. There remain first-order questions about the significance of MORB geochemical variability.

Early geochemical work proposed that the compositional variability of MORBs results from variations in the extent of mantle melting caused by highly variable $\left(250^{\circ} \mathrm{C}\right)$ potential temperatures [1]. Later data assessment concluded that chemical variability is instead caused by mantle composition [2]. More recent work with minor and trace elements highlighted that chemical variability reflects both mantle source and crustal processing [3]

We present new high-resolution and precision trace element maps of clinopyroxene from the gabbro sequence recovered in ODP Hole 735B (Atlantis Bank oceanic core complex, Southwest Indian Ridge) in search of preservation of magma differentiation processes in a slow-spreading ridge. Maps of the slowest diffusing elements, including $\mathrm{Cr}, \mathrm{Ti}, \mathrm{Zr}$ and $\mathrm{Hf}$, unveil complex internal chemical structure within crystal cores. Systematic $\mathrm{Cr}$ zonations suggest repeated replenishment with mafic magma, together with crystal resorption before the growth of crystal rims. Complex clinopyroxene zoning occurs towards the bottom of the studied stratigraphy, below $400 \mathrm{~m}$ below sea floor, where gabbros are more primitive [4]. These apparently repeated intrusions of primitive magma fit well with the replenish-mix-tap-crystallise (RMTX) cycles hypothesised to build the oceanic crust [3].

The clinopyroxenes also show ubiquitous enrichment in incompatible elements at crystal rims, probably caused by melt percolation from reactive porous flow [4]. Combined, the textural and compositional features within the gabbro sequence indicate the development of mushy reservoirs by cyclic supply of mafic melts. The evidence of these processes in the mineral record is partly obscured by diffusive re-equilibration even in this relatively unproductive crust.

[1] Klein \& Langmuir (1987). Journal of Geophysical Research 92, 8089-8115.

[2] Niu \& O'Hara (2008). Journal of Petrology 49, 633-664.

[3] O’Neill \& Jenner (2016). Journal of Petrology 57, 2163 2194.

[4] Boulanger et al. (2020). Frontiers in Earth Science 8, 554598 . 